\title{
INFORMÁCIÓS TECHNOLÓGIÁK ÉS MENEDZSMENT FOLYAMATOK, BPM
}

\author{
Dr. PhD. Marosi Tibor - Vukoszávlyev Szlobodan** \\ "föiskolai docens, Szegedi Tudományegyetem Mérnöki Kar \\ NESS FMC Kft.
}

\begin{abstract}
Summary
In consequence of continuous changing requirements of stakeholders, enterprises face hard market competition. They can suit the requirements with business processes worked out well. The standard challenges of the enterprises are keeping profit, retaining the competitiveness, process optimizing, and getting new markets. The best solution if they are aware their processes, and make an attempt at operate and improve these processes with the most effective tools. This paper makes an attempt to present relationship between informational technologies and business processes, and the significance and the benefit of using business process management (BPM).
\end{abstract}

\section{BEVEZETÉS}

Napjaink vállalkozásainak, - a folyamatosan változó piaci követelmények és az érdekeltjeik igényeinek egyre inkább kiszélesedő skálája következtében, - olyan mértékü piaci versennyel kell szembe nézniük, melynek csak megfelelöen kidolgozott üzleti folyamatokkal felelhetnek meg. Korunk vállalatainak folyamatos versenykihívásai közé tartozik a nyereségesség megtartása, versenyképesség megőrzése, a folyamat optimalizáció és az új piacok szerzése. Legjobb megoldást jelentheti, ha a vállalat tisztában van saját folyamataival és megpróbálja azt a leghatékonyabb eszközökkel müködtetni, javítani. A dolgozatban bemutatásra kerül az információs technológiák és az üzleti folyamatok kapcsolata, az üzleti folyamat menedzsment (BPM) jelentősége és alkalmazásának elönye.

\section{MINÓSÉGÜGYI FOLYAMATOK ÉS MÓDSZEREK}

Egy szervezet életében az eredményes múködés szükséges, de nem elégséges feltétele a sikernek. Ennek értelmében egy vezető cégnek nem elég egy jól müködő rendszerrel rendelkeznie, hanem állandó hangsúlyt kell fektetnie az üzleti folyamatok kidolgozására, nyomon követésére, karbantartására, dokumentálására és fejlesztésére, ha lépést akar tartani a piacon jelen lévő versenytársakkal. A hatékony mủködés alapja, ha felmérjük a rendelkezésre álló erőforráskészletet, azt megfelelően optimalizáljuk, majd ezt az eredményt használjuk fel a maximális profit eléréséhez. Költségcsökkentés érdekében a vállalatok vezetői hatalmas volumenü megtakaritási projektekbe fognak (többnyire eredménytelenül), mely során a legjelentősebb feladatra, a folyamàtok állandó ellenörzésére és fejlesztésére nem helyeznek elég hangsúlyt.

\section{Globalizáció és lokalizáció}

A globális piac kialakulásával a nemzetgazdasági versenytér globális versenytérré tágul, az információs technológiákkal támogatott gazdasági egységek érték elóállító folyamatai újradefiniálódnak. Ebben a térben a gazdasági tevékenységek folyamat-irányítási koncepcióval vezérelt, feladat-orientált gazdasági cselekvésekké válnak. A gazdaság 
globálisan szervezõdik, a megjelenő szervezeti formák újfajta küldetési tartalommal müködnek. Napjainkra a globálisan versenyképes kulcsvállalatok átformálódtak, hálózatosan szerveződtek és ezzel kialakítottak egy globális versenyerōt. A globális vállalati szervezödéssel párhuzamosan az innováció és a termelés helyileg alakul ki, lokalizálódik. A globális információs hálók bárhol elérhetővé válnak, amely elösegíti a technológia lokalizációját. A feladat-orientált gazdasági cselekvések döntéshozatali gócpontjai, és alanyai is újradefiniálódtak. A döntéshozatali gócok helye globálisan szüntelenül változik. A menedzsmentnek lokális döntéshozatali ereje gyengül, ezzel egy időben az alkalmazottak döntéshozatali ereje nỏ. Az újfajta vállalati szervezetek, a globális információs hálók és az újradefiniált döntéshozatali erők megjelenése egyre jobban kihangsúlyozza a regionális tevékenységek szerepét. [OMFB 1997]

\section{Üzleti folyamatok}

Az iparág méretétől függetlenül minden vállalat rendelkezik üzleti folyamatokkal, melyek nélkül egyikük sem létezhet. Amennyiben képes ezeket megfelelöen kezelni és optimalizálni, akkor ez versenyképességet fog biztosítani a piacon. A folyamatok részletes kidolgozása ugyanakkor azt is elősegíti, hogy egy vállalat még a piaci verseny elött kiszolgálja a vevöket a különböző termékekkel és szolgáltatásokkal valamint, hogy képes legyen azonnal reagálni a folyamatosan változó piaci követelményekre. Napjaink gazdaságában a profitorientált szervezetekre óriási nyomás nehezedik a költségek folyamatos csökkentése miatt, valamint a vásárlók által elvárt rendkívưl magas minőségi szint biztosításából adódóan. Az egyre inkább megújuló üzleti területek feltérképezése érdekében fontos feladatnak bizonyulhat az üzleti folyamatok célokkal való összekapcsolása.

\section{Információs technológiák}

Habár a múlt században széles körben elterjedt információs technológiák mélyreható változásokat okoztak a gazdaságban és a társadalomban is, legtöbben nem sejtjük milyen átalakulásokkal járhat egy információs forradalom. Csak egy példa, a kommunikáció gyorsulása és eszközeinek egyre könnyebb elérhetösége megváltoztatja az üzleti életet, a munkavégzés helyét és módját is. Az elektronikus kereskedelem egyrészt új kapcsolati rendszereket hoz létre, aminek sok előnyös oldala van, de ugyanakkor számos társadalmi problémát is felvet ( $p l$. bizalmasság kezelése). Az egyre bonyolultabb és összetettebb rendszerek irányítására szerveződött technológiák csak akkor müködhetnek jól, ha képesek modellezni és kezelni a valóságot. A nyolcvanas évektől kezdődően, az információs technológiák elỏretörésével, a tömegtermelés rendszere átalakult. Az információs technológia által kialakitott új szabályozás folyamatosan változik, az internet kialakulásával és növekedésével a gazdasági tranzakciók költségei csökkentek. A valóságos piacokon az adott terméknek több ára is lehet, a vevök és eladók közötti jelentős fizikai és térbeli távolság áll fenn, $\mathrm{s}$ ez a bizalom hiányához vezethet. Azok a cégek, amelyek nagyobb mértékü bizalomra képesek szert tenni, magasabb árakat állapíthatnak meg. [Gedeon, P] A tömegtermelés gazdasági fôlénye volt, hogy az előállitott terméket, és a termelési folyamatot szabványosította, részelemeire bontotta és beillesztette a központosított vállalati hierarchia rendszerébe. Az információs technológia alkalmazása a vállalati irányítási formák átalakulásával jár. Castells a globalizáció és az információs technológia ősszefüggésébe álítva mutatja be a hagyományos vállalati szerkezet átalakulását, a hálózati vállalat megjelenését [Castels, $\mathrm{M}$ ] $\mathrm{Az}$ információs technológia szükségszerủen megköveteli a decentralizációt vagyis a központosított hierarchia felbontását. Az információs technológiák lehetővé teszik, hogy a vállalatok a hierarchiát a piaccal helyettesítsék vagy egészitsék ki. 
Jellemzően akkor választják a piaci koordinációt, ha a piacról történő beszerzés kőltségei alacsonyabbak az előállításhoz kapcsolódó költségeknél. A korábbi, centralizált nagyvállalat átalakul, szervezeti egységei olyan globálisan versengő piaci egységekké válnak, amelyeket a vállalati központ koordinál [Kocsis É, Szabó K].

Az információs technológiák alkalmazásának négy lépcsőfoka van [Pomázi, l]:

- Adatgyüjtés és feldolgozás

- Az adatok információvá alakítása (tanulási folyamat az információk hasznosításában)

- Az információ átalakítása tudássá

- A tudás „bölcs" felhasználása (a fenntarthatóság érdekében)

\section{Folyamatszervezés és optimalizálás}

A vállalatot úgy lehet jellemezni, mint olyan folyamatok hálózatát, amelyek meghatározhatók, dokumentálhatók, ellenőrizhetők és fejleszthetők. A hagyományos szemléletü környezetben a szervezetek közti problémákat rendszerint a legmagasabb szinten oldják meg. Mivel azonban a felső menedzserek hiányában vannak a problémamegoldáshoz szükséges ismereteknek, a megoldás rendszerint nem időben történik; illetve nem megfelelỏen. A folyamatszemlélet és folyamatorientáltság nem más, mint a vállalat meghatározható, dokumentálható, ellenörizhető és fejleszthető folyamati hálózatként történő értelmezése és kezelése. [IFUA Horváth \& Partners]

A folyamatszervezés a vállalatvezetés sikerének alapját jelenti akkor, amikor a vevök követelményei folyamatosan változnak, nőnek, és a sokrétü termékkínálat komplex struktúrák kialakítását teszi szükségessé. A folyamatorientált minöségügyi rendszer, a folyamatok azonosításán, dokumentálásán túl, a folyamatoknak a vállalati stratégiához, a vevők követelményéhez történő folyamatos igazítását jelenti. A konzekvens folyamat-optimalizálás, a meghatározott folyamatjellemzök, valamint a célokhoz történő igazodás vezet végül a folyamatoptimalizálás igazi céljához, az ủzleti eredmények javításához. Fontos, hogy a folyamatok minőségét megfelelő indikátorokkal mérjék, regisztrálják, és szükség szerint beavatkozzanak. A folyamatban tehát mérési, ellenőrzési pontokat, jellemzőket kell meghatározni, és alkalmas módszerekkel felügyelni. Számos vállalat mükődésében több olyan tényezőt is tapasztalhatunk, mely elösegítheti a fejlődését, valamint átlátható képet mutathat a megfelelő müködésröl.

\section{1. ábra Az üzleti folyamatok kezelésével létrejövõ megtakarítások határai}

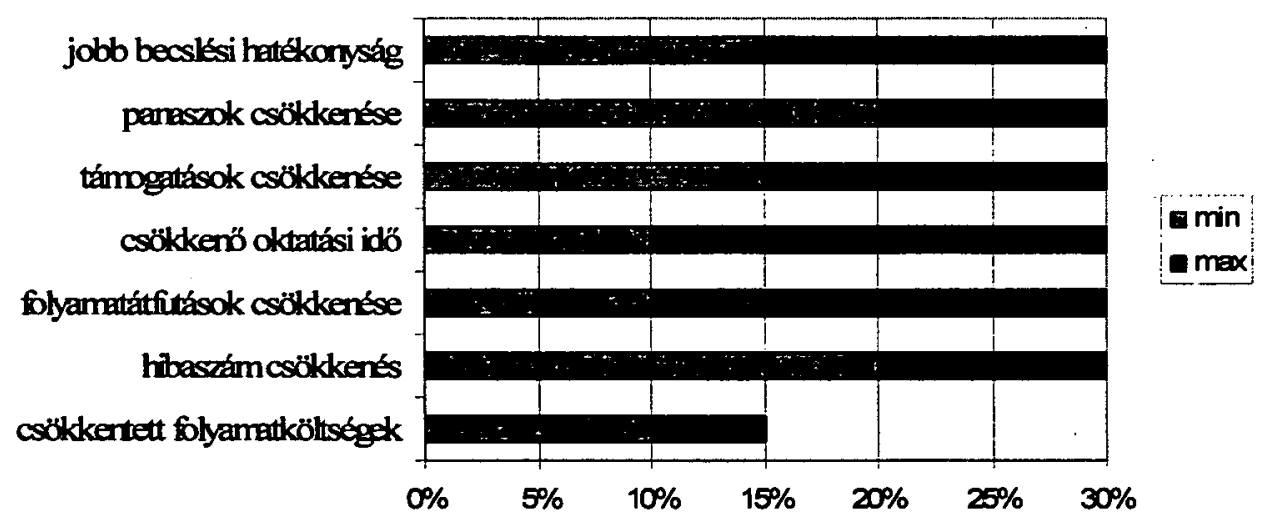


Tanácsadó cégek által készült tanulmányok azt bizonyítják, hogy a folyamatok irányítására használt rendszerek nagyban megkönnyithetik egy vállalkozás piacon történō folyamatos fennmaradását. [ARIS Solution for Enterprise BPM] Az 1. ábra bemutatja, hogy az üzleti folyamatok megfelelő kezelése és irányítása következtében, milyen határok közötti költség, idő, hiba és egyéb megtakaritások érhetők el [ARIS Platform User Guide].

\section{ÜZLETI FOLYAMAT MENEDZSMENT (BPM')}

Az üzleti folyamat menedzsment az információ technológia és a menedzsment metszéspontjából létrejött olyan tudományág, mely az operatív üzleti folyamatok módszereinek, technikáinak és eszközeinek, tervezésével, irányításával és elemzésével foglalkozik, felhasználva az emberi erőforrásokat, alkalmazásokat, dokumentációkat és kủlönböző információforrásokat. [ARIS Platform User Guide] A folyamatosan változó vezetés és az üzleti folyamatok átszerveződésének fontossága miatt a BPM lényeges eszkőzévé vált a vállalatok elörehaladásának. Olyan vezetõi folyamatok épülhetnek bele a mindennapi tevékenységi körbe, melyek óriási szerepet játszanak az egyesített stratégia meghatározásában, valamint a stratégiai célok alkalmazásában. Az előző állítás eredményeképpen megállapithatjuk, hogy az üzleti folyamatstratégia tervezése és alkalmazása alapvető jelentőséggel bír a vállalati életben. Ebben az értelemben a BPM az üzleti folyamatok, valamint a hozzájuk kapcsolt szervezeti- és információtechnológiai struktúrák rendszeres alkalmazását jelenti, természetesen a piaci követelményeknek megfelelően. Bármely vállalkozás számára óriási kihívást jelenthet egy olyan információ technológiai rendszer összehangolása, mely az évek során rendkívül összetetté képes fejỏdni. Miközben a cégek arra törekszenek, hogy különféle „,ár-csökkentő" módszereket alkalmazva alacsonyabb költségeket érjenek el, az általuk használt informatikai rendszerek mégsem bizonyulnak elég hatékonynak. A fenntartható fejlödés és a jelentös költségcsökkentés egyetlen módja az, ha felsorakoztatjuk a vállalkozás céljait, valamint üzleti folyamatait, és ezek alapján próbáljuk meg kifejleszteni a különböző minőségügyi rendszereket.

$\mathrm{Az}$ üzleti folyamat menedzsmentet tömören egy olyan tudományágként is meghatározhatjuk, mely megbízható irányítást biztosit az üzleti folyamatok környezetében, a gyorsaság és operatív teljesítmény elérésével. Más néven a BPM egy strukturált megközelitésmód, mely módszereket, eljárásokat, vezetői gyakorlatokat és szoftver eszközöket alkalmaz egy szervezet tevékenységeinek és folyamatainak állandó nyomon követésében. Tulajdonképpen nagyon sokan félreértik a BPM lényegét. Néhányan az üzleti folyamatok kezelésének egy újabb területének gondolják, mások a folyamatok szabványosításának tartják [ARIS Solution for Enterprise BPM].

- A BPM nem egy projekt - a folyamatok fejlesztése az üzleti folyamatok irányításának állandó kimenete.

- A BPM nem csak egy technológia - a BPM a vezetés gyakorlása, és bizonyos technológiák elősegítik e gyakorlat fejlesztését.

- Az üzleti folyamat nem egy szoftveralkalmazás - sokféle üzleti folyamatot bizonyos személyek irányítanak, nem pedig egy program segítségével oldják meg.

- A BPM nem a folyamatok szabványosításáról szól - a jobb folyamat menedzsment, a legmegfelelőbb folyamatok alkalmazásához vezet, habár a BPM gyorsaságot, fejlödést és részletességet is biztosit.

\section{BPM nyújtotta elōnyök}

A vállalatok hosszú távú sikere (beleértve az árbevételt és profitot) a saját folyamatirányitásának sikeres meghatározásán alapul. A kérdés csak az, hogy vajon mennyire 
hatékony az a folyamat, mely lehetővé teszi a szervezeti egységek és információtechnológiai készletek átalakítását?

Egy információtechnológiai beruházás valódi értékét az határozza meg, hogy milyen módon képes támogatni és irányítani a vállalaton belüli összetett folyamatokat. $\mathrm{A}$ fent említett nézet alkalmazásával egyes nemzetközi szervezetek potenciális megtakaritásokat és nyereségeket elérve óriási segítséget tudnak nyújtani vevőiknek és a támogatóiknak, a vállalati folyamatok részletes feltérképezésével kapcsolatban. A BPM folyamatos fejlesztése elengedhetetlen elöfeltétele a piaci versenyképesség fenntartásának valamint újítási lehetöségek kialakításának, ezért is van szükség arra, hogy nagy hangsúly kerüljön a termék elöállításhoz kapcsolódó folyamatokra (piaci naprakészség, fejlesztés), a termelés és szolgáltatás ellátására (vevő központúság, profit árrés, minőség), támogatásra (csökkentett fixköltség, nagyobb munkavállalói elégedettség), valamint a vezetésre és nyomon követésre (változás menedzsment, stratégia).

Tehát ha megfelelően alkalmazzák a BPM-et, akkor valóban képes lesz segíteni abban, hogy minél gyorsabban és rugalmasabban reagáljunk a folyamatosan változó vevői követelményekre és piaci irányzatokra. Egy ilyen típusú folyamat-orientált megközelítési módot alkalmaznak az informatikai alkalmazások kifejlesztésében is, melyek egy vállalkozás sikerességében rendkívül fontosnak bizonyulhatnak (mint például az ERP, CRM és SCM rendszerek ${ }^{2}$ ), továbbá óriási hangsúlyt fektetnek a folyamatok egyidejủ optimalizálására. Az ilyen típusú rendszerek segítségével, az üzleti folyamatok költségeihez kapcsolódva valamint a folyamatok állandó nyomon követéséből adódóan lehetöség nyílik a befektetések megtérülésére $\left(\mathrm{ROI}^{3}\right)$.

JEGYZETEK

${ }^{1} \mathrm{BPM}=$ Business Process Management

${ }^{2}$ ERP-Enterprise Resource Planning, CRM-Customer Relationship Management, SCM-

Supply Chain Management

${ }^{3}$ Return on Investment

\section{IRODALOMJEGYZÉK}

ARIS Platform User Guide: IDS Scheer AG, Saarbrücken 2007

ARIS Solution for Enterprise BPM: IDS Scheer AG, Saarbriicken 2007

Castells, Manuel, The Information Age: Economy, Society and Culture, Vol.1. Cambridge, MA; Oxford, UK 2000

Dr. Pomázi István, A fenntartható fejlődés megvalósitásának alternatívái a technológiai fejlődés tükrében, NKTH tanulmány (http://www.nkth.gov.hu)

Gedeon Péter, A mobil információs technológia hatása a gazdaságra, Mobil információs társadalom: Tanulmányok szerk. Nyíri Kristóf, Budapest: MTA Filozófiai Kutatóintézete, 2001.

IFUA Horváth \& Partners, Folyamatmenedzsment a gyakorlatban, IFUA Horváth \& Partners Budapest, 2006

Kocsis Éva és Szabó Katalin, A posztmodern vállalat. Tanulás és hálózatosodás az új gazdaságban. Budapest: Oktatási Minisztérium, 2000.

OMFB Innováció és versenyképesség, OMFB 9607-01. és 9607-10. sz. kutatás 1997 